\title{
REGENERATION OF DRAGON FRUIT (HYLECEREUS UNDATUS) PLANT- LETS FROM LEAF AND STEM EXPLANTS
}

\author{
Dahanayake $\mathrm{N}$ and Ranawake AL \\ Department of Agricultural Biology, Faculty of Agriculture, University of Ruhuna, Sri Lanka
}

Accepted : 06 October 2011

\begin{abstract}
Dragon fruit (Hylocereus undatus) (Cactacea) is a climbing vine which has received worldwide attention, first, as an ornamental plant and then extended as a fruit crop. Since seed viability of stored dragon fruit is very low, stem cuttings are used as planting material in Dragon fruit. Though several studies have examined different propagation methods for Dragon fruit; very little information is available on protocols for production of high quality planting material via tissue culture. In the present study we examined the potential of direct shoot regeneration of Dragon fruit explants using leaf and stem cuttings obtained from in vitro germinated seedlings in 3 different concentrations of Benzylaminopurine (BA) 2, 2.5, 3mg/l supplemented with $0.01 \mathrm{mg} / \mathrm{l}$ NAA to the Murrashige and Skoog (MS) basal regeneration medium. Thereafter regenerated plantlets from direct organogenesis from all explants were rooted in MS basal medium supplemented with $0.01 \mathrm{mg} / 1$ NAA (Naphthaleneacetic acid).

Results revealed that the type of explants greatly influences the regeneration ability of shoot buds. Stem explants exhibited much higher regeneration ability (18 buds/explant) than leaf explants (3 buds/ explant) without vitrification. Within 4 weeks, buds were initiated on explants on MS basal medium supplemented with $2.5 \mathrm{mg} / \mathrm{l} \mathrm{BA}$ and $0.01 \mathrm{mg} / \mathrm{l} \mathrm{NAA}$ and buds took nearly 60 days to elongate to $1.5 \mathrm{~cm}$ on the same medium. Stem and leaf explants, regenerated the highest number of shoots on MS medium supplemented with $2.5 \mathrm{mg} / \mathrm{l} \mathrm{BA}$ and $0.01 \mathrm{NAAmg} / \mathrm{l}$ compare to that of the other hormone combinations. Rooting was observed in regenerated mature shoots after transferred onto MS basal medium with $0.01 \mathrm{mg} / \mathbf{l}$ NAA.
\end{abstract}

Key words: Dragon Fruit, Direct Regeneration, MS Medium

\section{INTRODUCTION}

Dragon Fruit belongs to family Cactaceae and grows best in dry, tropical or subtropical climates where annual rainfall ranges from 20$50 "$ per year. The fruit of this crop is popular and eaten chilled. It is also used to flavor drinks and pastries. Unopened flower buds are cooked and eaten as vegetables (www. Tradewindsfruit.com).

Dragon fruit is usually propagated by seeds or cuttings. Plant tissue culture is an alternative method for large scale plantlet production. Although several studies have examined these general propagation methods of dragon fruit, no widely available information currently exists on the protocols for the production of high quality planting material of Dragon fruit via the tissue culture system. Some researchers (Lichtenzveig 2000; Castillo 2003; Le Bellec, 2004) have developed protocols for micropropagation of Dragon fruit but these reports lack the comprehensive key information on the large scale production of Dragon fruit planting

\footnotetext{
*Corresponding author: nilanthi@agbio.ruh.ac.lk
}

materials.

This study was conducted to establish an efficient micro-propagation protocol for Dragon fruit so that more plantlets with healthy shoot and root system can be produced to meet the demand of increasing commercial cultivation.

\section{METHODOLOGY}

Seeds of Dragon fruit (Hylocereus undatus) were sterilized and cultured on MS basal medium and aseptic plantlets were obtained. Stem and leaf cuttings of aseptic in vitro plantlets were used for direct shoot regeneration on three different shoot regeneration media (BA $2,2.5,3 \mathrm{mg} / 1$ supplemented with $0.01 \mathrm{mg} / 1$ NAA on the MS basal medium). Well developed and elongated shoots up to $1.5 \mathrm{~cm}$ were transferred to root induction medium $(0.01 \mathrm{mg} / 1$ NAA on the MS basal medium).

\section{Plant materials}

Seeds of red Dragon fruit were extracted from a fresh ripe fruit which has been purchased from a cultivated field in Sri Lanka and were 
used for the present study. Seeds were extracted from two different types of fruits; fresh fruits and fruits those were stored for three months in a refrigerator. Aseptic cultures of Dragon fruit were established via in vitro plantlet regeneration.

\section{Establishment of aseptic seed cultures}

Seeds were over night soaked separately and surface-sterilized by spraying $70 \%$ ethanol for 2 minutes and dipping in 1\% sodium hypochlorite solution containing 6\% Tween 20 for 10 minutes. Sterilized seeds were then properly washed out with autoclaved distilled water and cultured on MS medium with $1 \%$ sucrose and $0.5 \%$ agar and kept at $25^{0}-27^{0} \mathrm{C}$ with 12 -h photoperiod under florescent light $\left(50 \mu \mathrm{mol} \mathrm{m}^{-2} \mathrm{~s}^{-1}\right)$. Two surface sterilized seeds were planted in each glass vessel with $2 \mathrm{ml}$ of MS medium. Explants were obtained 4 weeks after culturing.

\section{Preparation of culture media}

All the media used were adjusted to $\mathrm{pH}$ value of 5.6 prior to autoclave at $1.4 \mathrm{~kg} / \mathrm{cm}^{2}$ for 20 minutes.

\section{Investigation of the shoot induction ability of calli derived from different explants}

Healthy plantlets were randomly selected as an explant source. Leaf and stem explants of aseptic plantlets were cultured on MS basal medium supplemented with $2,2.5,3 \mathrm{mg} / 1 \mathrm{BA}$ and $0.01 \mathrm{mg} / 1 \mathrm{NAA}$ to investigate the regeneration ability of explants. In cultures, leaves were cut into sections $\left(0.5 \mathrm{~cm}^{2}\right)$ and placed on media with the adaxial surface toward the media. Stems were cut into $5 \mathrm{~mm}$ pieces and cultured on MS basal medium horizontally. The optimum regeneration ability of leaf and stem explant were determined. Experiment was done according to Complete Randomized Design (CRD) with 10 replicates and experiment was repeated three times. Sub culturing was done after 2 weeks and two sub-culturing events were done. Cultures were kept under 16 hours cycled fluorescent light cooled incubators with temperature regulated at $25 \pm 1{ }^{\circ} \mathrm{C}$.

\section{Rooting of adventitious buds on root induc- tion medium}

Healthy shoots regenerated from all explant types longer than $1.5 \mathrm{~cm}$ were separated and cultured on MS basal medium containing 0.01 $\mathrm{mg} / \mathrm{l}$ NAA to induce rooting. All treated ex- plants were kept under light $\left(50 \mu \mathrm{mol} \mathrm{m} \mathrm{m}^{-2} \mathrm{~s}^{-1}\right)$ condition with a 12 -h photoperiod at $25^{\circ} \mathrm{C}$ for 40d.

\section{Data collection and analysis}

Regenerated cultures were evaluated 60 days after initiation of the buds. Statistical analysis was carried out using the Student NewmanKuells Means Separation Test of SAS (SAS Institute, 1995).

\section{RESULTS AND DISCUSSION}

\section{Plant source}

Seeds stored more than three months at $10^{\circ} \mathrm{C}$ had significantly lost seed viability. Thus, freshly extracted seeds were more suitable for the production of explants. Seeds which were directly extracted from fresh fruit were used for the production of explants in tissue culture medium (Fig 1). Stem and leaf cuts of tissue culture grown plantlets were cultured on direct regeneration media (Fig. 2).

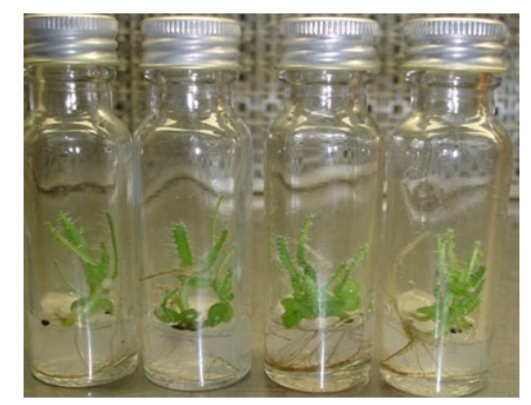

Fig 1. In-vitro planted seedlings in culture conditions

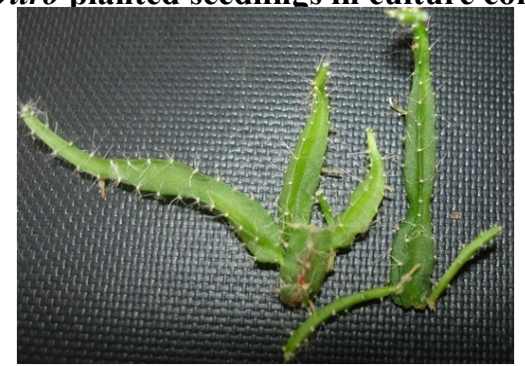

Fig 2. Regenerated In-vitro plantlets grown on 2.5 $\mathrm{mg} / \mathrm{l}$ BAP with $0.01 \mathrm{mg} / \mathrm{l}$ NAA on MS basal medium

\section{Investigation of the shoot induction ability} of calli derived from explants

Stem-explants recorded 6.25-18 regenerated buds/explant while leaf-explant recorded 0.25 3 regenerated buds/explant in regeneration media regardless of the constitution.

Difference in explant type greatly influenced the regeneration of shoot buds on tissue culture media in different BA concentrations (Table 1). 
Whatever the medium, stem explants recorded higher number of regenerated buds/explants compare to that of leaf cuttings.

Table 1: Regeneration of shoots from different explant types and different hormone (BA) concentrations

\begin{tabular}{lll}
\hline $\begin{array}{l}\text { Explant } \\
\text { type }\end{array}$ & $\begin{array}{l}\text { Hormone concen- } \\
\text { tration }(\mathrm{BA} \mathrm{mg} / \mathrm{L})\end{array}$ & $\begin{array}{l}\text { Number of shoots regen- } \\
\text { erated (Shoots/ explants) }\end{array}$ \\
\hline Stem & 2.0 & $6.2^{\mathrm{c}}$ \\
& 2.5 & $18.0^{\mathrm{a}}$ \\
& 3.0 & $10.2^{\mathrm{b}}$ \\
Leaf & 2.0 & $0.2^{\mathrm{b}}$ \\
& 2.5 & $3.0^{\mathrm{a}}$ \\
& 3.0 & $1.0^{\mathrm{b}}$ \\
\hline
\end{tabular}

Means fallowed by the same lower case letters are not significantly different at 5\% level in Duncan's Multiple Range Test.

\section{Capacity of plantlet production with the es- tablished methods}

It took 60 days to regenerate buds into $1.5 \mathrm{~cm}$ height, and stem explants showed a higher regeneration potential compared to that of leaf explants (Fig. 3). The stem explants produced the highest number of shoots (18 shoots/ explants) in MS medium supplemented with 2.5 $\mathrm{mg} / \mathrm{l} \mathrm{BA}$ and $0.01 \mathrm{mg} / \mathrm{l} \mathrm{NAA} \mathrm{(Table} \mathrm{1).} \mathrm{Highest}$ shoot production from leaf explants was also observed on shoot induction medium supplemented with $2.5 \mathrm{mg} / 1 \mathrm{BA}$ and $0.01 \mathrm{mg} / 1 \mathrm{NAA}$ (Table 1). Stem explants grown in this medium initiated callus at the cut surface in the fourth week, and three weeks after callus induction the calli began to produce multiple shoot primordia, which differentiated into adventitious buds or shoots. Increasing BA concentration up to $2.5 \mathrm{mg} / 1$ from $2 \mathrm{mg} / 1$ resulted in increasing shoot initiation and reduced further callus growth in both explants stem and leaf (Table 1). Regeneration was low in calli derived from leaf explants compare to that of calli derived from stem explants though they were grown on the same MS medium containing the same concentrations of BA. There was a significant interaction $(\mathrm{P}<0.05)$ between explant type and hormone concentration (BA) on regeneration of shoots.

\section{Rooting of the regenerated shoots}

When the shoots reached to $1.5 \mathrm{~cm}$ height they were transferred to root induction medium supplemented with $0.01 \mathrm{mg} / \mathrm{l} \mathrm{NAA}$ in MS basal medium. Plantlets produced brownish branched slim roots on root induction media within 2 weeks after transferring (Fig. 3).

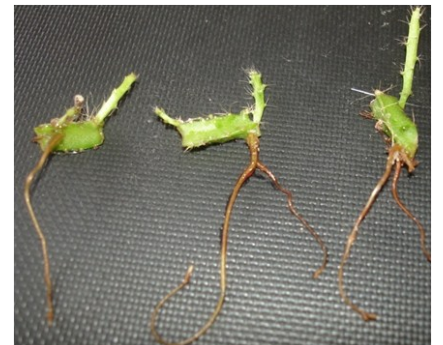

Figure 3: Regenerated In-vitro plantlets grown on $2.5 \mathrm{mg} / \mathrm{l}$ BA with on $0.01 \mathrm{mg} / \mathrm{l}$ NAA on MS medium. Root induced on $0.01 \mathrm{mg} / \mathrm{l}$ NAA supplemented MS medium

\section{DISCUSSION}

Plant tissue culture is an alternative technique that can be manipulated according to the plant species and explant type of the plant for large scale planting material production. Several researchers have developed protocols for micro propagation of yellow Dragon fruit ((Yassen, 2002; Tel-Zur, 2004). However, these reports lack the comprehensive key information on the large scale production of yellow Dragon fruit planting materials (http://reddragonfruits.blog spot.com/2008/02/disease-free-dragon-fruit-pla nting.html).

Red Dragon fruit is the commonly available fruit type in Sri Lanka. In the present study we developed in vitro protocol for micro - propagation of red Dragon fruit. In vitro technology is a very profitable, faster and efficient method comparatively other conventional plant propagation methods (Choffe et al. 2000). In vitro plantlets production satisfies the market demand of planting materials of many species (http://en.wikipedia.org/wiki/Plant tissue cult ure). According to the available literature, Murrashige and Skoog nutritious medium, with 3 $\mathrm{mgl}^{-1}$ of 2,4-dichlorophenoxyacetic acid (2,4D) was used for the callus growing of Mammillaria luethyi which belongs to the same family of Cactacea to which Dragon fruit is also belonged (http://www.uaaan.mx/DirInv/ Resul_PI- 04/MEMORIA_2004/Biotecnologia/ LEscobedoBocardo.doc).

Culturing seeds which were stored three months in the refrigerator failed to germinate though we provided proper conditions on MS basal medium. Loss of seed viability of Dragon fruit within a short period of time may be the reason for failure of seed germination. Seeds which were directly extracted from fresh fruits 
gave higher number of plantlets from the cultured on MS basal medium in this study. Dragon fruit is recalcitrant whose seeds loss viability after storing at low temperatures.

Shoot regeneration rate depends on the type of explants (Pickens etal. 2006) in in vitro plant production. Culturing of stem cuttings produces much proliferated shoots than that of leaves in Dragon fruit (Table 01). This is in agreement with Dahanayake et al. (2010) and Sauve et al. (2004) those reported that stem cuttings of Echinacea purpurea and stem cuttings of Echinacea tennesseensis produced much shoots from stem explants than the explants of leaves on MS basal medium supplemented with $0.3 \mathrm{mg} / 1 \mathrm{BA}$ and $0.01 \mathrm{mg} / 1 \mathrm{NAA}$ and supplemented with NAA at $0.54 \mu M$ and thidiazuron (TDZ) respectively. Shoots were regenerated in two steps in this protocol; first explants were cultured on shoot proliferation medium and then proliferated shoots were again cultured on root induction medium. This was help to select healthy shoots with good appearance to induce root to develop into complete plantlets.

By culturing the proliferated whitish friable calli derived from cut surface of the stem and leaf explants on MS basal medium supplemented with $2.5 \mathrm{mg} / 1 \mathrm{BA}$ with $0.01 \mathrm{mg} / 1 \mathrm{NAA}$, large number of shoots could be produced within 60 days. Shoot proliferation was higher in calli produced from stem cutting than that of leaf cuttings. The similar results were reported by Franklin et al. (2004) in soybean, in cucurbites (David et al.1990) in rice (Pádua, 1998) and in wheat (Anwaar, 2002). This would be the reason that stem cuttings had a better regeneration potential in red Dragon fruit.

Root induction of proliferated shoots was obtained on MS medium supplemented with and $0.01 \mathrm{mg} / 1 \mathrm{NAA}$ regardless of the shoot induction medium. This is in agreement with Dahanayake et al. (2010) and Sauve et al. (2004) where they reported that root induction is independent from shoot induction.

This novel and high efficient shoot regeneration protocol for the explant of stem and leaf of red Dragon fruit is promising for rapid propagation of elite genotypes of Dragon fruit. It is obvious that making full use of both stem and leaf explant source can effectively increase the number of regenerated buds from a certain plantlet.

\section{CONCLUSION}

Explants of stem and leaf dissected from in vitro germinated seedlings of red Dragon fruit produced 18 buds/stem cutting and 3 buds/leaf cutting on MS medium supplemented with $2.5 \mathrm{mg} / 1 \mathrm{BA}$ with $0.01 \mathrm{NAA} \mathrm{mg} / 1$ within 60 days. Stem cuttings exhibited much efficient plantlet production than that of leaf cuttings in the same regeneration medium. MS basal medium supplemented with $0.01 \mathrm{mg} / 1$ NAA induced root formation from regenerated shoots. This protocol can be used for the mass production of Dragon fruit in in vitro method.

\section{REFERENCE}

www. Tradewindsfruit.com

http://reddragonfruits.blogspot.com/2008/02/ disease-free-dragon-fruit-planting.html

http://www.uaaan.mx/DirInv/Resul_PI-4/MEMOR IA_2004/Biotecnologia/LEscobedoBocardo.doc

http://en.wikipedia.org/wiki/Plant_tissue_culture SAS Institute, Cary, NC, 1995

Anwaar A, Heng Z, Wengling Wang and Mariam B. Sticklen 2002 Shoot Apical Meristem: In vitro Regeneration and Morphogenesis in Wheat (Triticum aestivum L.) In Vitro Cellular \& Developmental Biology. Plant 38(2) 163-167.

Castillo RM Livera MM, Alicia E, Brechú F, Márquez-Guzmán J 2003 Compatibilidad sexual entre dos tipos de Hylocereus (Cactaceae), Rev. Bio. Trop. 51; 699-706.

Choffe JMR, Victor SJ, Murch and Saxena PK 2000 In vitro regeneration of Echinacea purpurea L: Direct somatic embryogenesis and indirect shoot organogenesis in petiole culture. In Vitro Cell Develop -Plant 36(1):30-36.

Curcurbitaceae [sic] Comstock Pub. Associates, 1990 - Technology \& Engineering - 485.

Dahanayake N, Xiao-Lu Chen, Fu-Cheng Zhao, Yue-Sheng Yang and Hong Wu 2010. An Efficient In Vitro Propagation System for Purple Cone-Flower (Echinacea Purpurea L) Journal of Tropical Agricultural Research \& Extension 13(2): 29-32.

Franklin G, Carpenter L, Davis E, Reddy CS, AlAbed D, Alaiwi WA, Parani M, Smith B, Goldman SL and Sairam RV 2004. Factors influencing regeneration of soybean from mature and immature cotyledons. Plant Growth Regul. 43:73-79.

Le Bellec F 2004 Pollinisation et fecundation d' $\mathrm{Hy}$ locereus undatus et d'H. costaricensis àl'île de 
la Réunion, Fruits 59; 411-422.

Lichtenzveig J, Abbo S, Nerd A, Tel-Zur N and Mizrahi Y 2000 Cytology and mating systems

in the climbing cacti Hylocereus and Selenicereus, Am. J. Bot. 87; 1058-1065.

Pádua VLM, Fernandes LD, Oliveira DE de and Mansur E 1998. Effects of Auxin and Light Treatments of Donor Plants on Shoot Production from Indica-Type Rice (Oryza sativa). In Vitro Cellular \& Developmental Biology. Plant 34(4): 285-288.

Pickens KA, Cheng ZM and Kania SA 2006 Effects of colchicine and orizalin on callus and adventitions shoot formation of Euforbia pulcherrima 'Winter Rose'. HortScience, 41: 16511655.

Sunandakumari C, Zhang CL, Martin KP, Slater A and Madhusoodanan PV 2005 Effect of auxins on indirect in vitro morphogenesis and expression of gusA transgene in a lectinaceous medicinal plant, Euphorbia nivulia Buch.-Ham. In Vitro Cellular and Developmental BiologyPlant, 41: 695-699.

Sauve JR, Mmbaga TM and Zhou S In vitro regeneration of the Tennessee coneflower (Echinacea tennesseensis). In Vitro Cell. Dev. Biol.-Plant, 2004, 40:325-327.

Tel-Zur N, Abbo S, Bar-Zvi D and Mizrahi Y 2004 Clone identification and genetic relationship among vine cacti from the genera Hylocereus and Selenicereus based on RAPD analysis, ci. Hortic. 100; 279-289.

Yassen MY 2002 Micropropagation of pitaya (Hylocereus undatus Britton \& Rose) In Vitro Cell. Dev. Biol.-Plant 38; 427-429. 